\section{PROBABILISTIC GLYCEMIC CONTROL DECISION SUPPORT IN ICU: PROOF OF CONCEPT USING BAYESIAN NETWORK}

\author{
Asma Abu-Samaha*, Normy Norfiza Abdul Razakb, Fatanah \\ Mohamad Suhaimic, Ummu Kulthum Jamaludind, Azrina Md Ralibe
}

alnstitute of Energy Infrastructure, Universiti Tenaga Nasional, Jalan Ikram-UNITEN, 43000, Kajang, Selangor, Malaysia

bDepartment of Electronics and Communication, Universiti Tenaga Nasional, Jalan Ikram-UNITEN, 43000, Kajang, Selangor, Malaysia cAdvanced Medical \& Dental Institute, Universiti Sains Malaysia, Bertam, 13200, Kepala Batas Penang, Malaysia dHuman Energy Focus Group, Universiti Malaysia Pahang, 26600, Pekan, Pahang, Malaysia

eDepartment of Anesthesiology \& Intensive Care, International Islamic University Malaysia, 25200, Kuantan, Pahang, Malaysia
Article history

Received

30 August 2018

Received in revised form

22 November 2018

Accepted

26 November 2018

Published online

18 February 2019

\section{*Corresponding author} Asma@uniten.edu.my

\section{Graphical abstract}

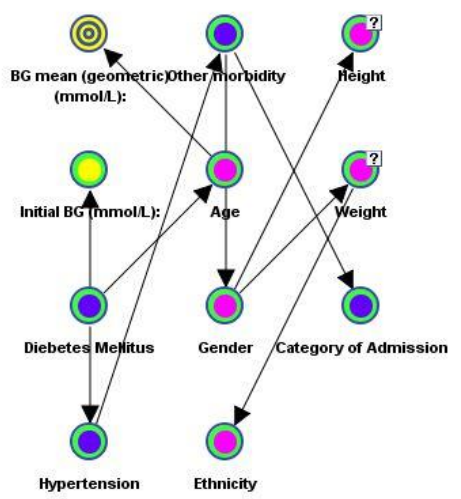

\begin{abstract}
Glycemic control in intensive care patients is complex in terms of patients' response to care and treatment. The variability and the search for improved insulin therapy outcomes have led to the use of human physiology model based on per-patient metabolic condition to provide personalized automated recommendations. One of the most promising solutions for this is the STAR protocol, which is based on a clinically validated insulin-nutrition-glucose physiological model. However, this approach does not consider demographical background such as age, weight, height, and ethnicity. This article presents the extension to intensive care personalized solution by integrating per-patient demographical, and upon admission information to intensive care conditions to automate decision support for clinical staff. In this context, a virtual study was conducted on 210 retrospectives intensive care patients' data. To provide a ground, the integration concept is presented roughly, but the details are given in terms of a proof of concept using Bayesian Network, linking the admission background and performance of the STAR control. The proof of concept shows $71.43 \%$ and $73.90 \%$ overall inference precision, and reliability, respectively, on the test dataset. With more data, improved Bayesian Network is believed to be reproduced. These results, nevertheless, points at the feasibility of the network to act as an effective classifier using intensive care units data, and glycemic control performance to be the basis of a probabilistic, personalized, and automated decision support in the intensive care units.
\end{abstract}

Keywords: Personalized Medicine Approach, Glycemic Control, Intensive Care Unit, Decision Support, Bayesian Network 


\begin{abstract}
Abstrak
Kawalan glisemik dalam pesakit kritikal di unit rawatan rapi adalah rumit dari segi tindak balas pesakit terhadap penjagaan dan rawatan. Sifat keberubahan individu dan pencarian hasil terapi insulin yang lebih baik telah membawa kepada penggunaan model matematik fisiologi manusia berdasarkan keadaan metabolik pesakit untuk memberikan cadangan rawatan secara individu. Salah satu penyelesaian yang paling menjanjikan harapan adalah protokol STAR yang berdasarkan kepada model fisiologi insulin-nutrisi-glukosa yang telah disahkan secara klinikal. Namun pendekatan ini tidak mengambil kira latar belakang demografi seperti umur, berat, ketinggian dan etnik. Artikel ini membentangkan lanjutan kepada penyelesaian rawatan secara peribadi mereka dengan mengintegrasikan informasi demografi pesakit dan keadaan mereka semasa dimasukkan ke dalam unit rawatan rapi untuk mengautomasikan sokongan keputusan untuk kakitangan unit. Dalam konteks ini, satu kajian 'virtual' dilakukan pada data 210 pesaki. Sebagai kajian kes, konsep integrasi dibentangkan secara kasar, tetapi butiran diberikan dari segi bukti konsep yang menggunakan Rangkaian Bayesian, menghubungkan latar belakang kemasukan ke unit dan prestasi kawalan STAR. Bukti kajian kes menunjukkan $71.43 \%$ dan $73.90 \%$ ketepatan dan kebolehlaksanaan unjuran masing-masing dengan dataset ujian. Dengan lebih banyak data, rangkaian Bayesian yang lebih baik dipercayai boleh dihasilkan. Walaubagaimanapun, keputusan ini menunjukkan kemungkinan rangkaian ini bertindak sebagai pengelas yang berkesan dengan menggunakan data dari unit rawatan rapi dan prestasi kawalan glisemik untuk menjadi asas sokongan keputusan bersifat probabilistik, peribadi dan automatic dalam unit rawatan rapi.
\end{abstract}

Kata kunci: Pendekatan Perubatan Peribadi, Kawalan Glisemik, Unit Rawatan Rapi, Dokongan Keputusan, Rangkaian Bayesia

(C) 2019 Penerbit UTM Press. All rights reserved

\subsection{INTRODUCTION}

Since the birth of intensive care medicine, researchers tend to study the cause and effect results of patients with similar signs and symptoms together under diagnoses, such as "sepsis", "diabetic", and "acute renal failure". They ignore a considerable non-uniformity within these groups in terms of individual characteristics; such as age, comorbidities condition, genetic predisposition, and individual variations in response to treatment. As technology and awareness of improved intensive care medicine has progressed, increasingly the personalized medicinal approach where patients must be treated as individuals, and not only with medical complications are entering the intensive care units (ICUs) [1-3]. However, it is only the beginning of glycemic control management, and despite the availabilities of automated recommendations for treatment, final judgements are practically left to the opinion of experts.

With the increasing amount of data generated from patients, in insulin to control blood glucose (BG) treatment strategies, as across all other ICU therapies, more and more control models are now being computerized [4]. With the objective of obtaining better (less hyperglycemia), and safer (less hypoglycemia) control, a growing number of ICUs are starting to use validated computer algorithms with a beneficial effect on a beneficial effect on glycemic control such as EndoTool, LOGIC and STAR [5-7]. These controls are based on improved clinical guidelines as well as improved physiological models, but none explicitly consider per-patient demographical background, and upon admission condition such as comorbidities.

STAR (Stochastic TARgeted) is a computerized glycemic control protocol that is based on insulin sensitivity to characterize and forecast changes in per-patient metabolic state, and is designed to be used in real-time bedside care. Its prediction is based on a stochastic model over the 1-3 hours subsequent potential variation in per-patient insulin sensitivity [810]. STAR has shown promising results in the ICU, and is currently being used in ICUs in Christchurch, New Zealand, and Gyula, Hungary. Since December 2016, it has been used in an ICU in Malaysia [11]. An unpublished study by a Malaysian research team has shown that the generalized performance of STAR [12] cannot be reproduced on Malaysian patients, and this raises the question of demographical impact on the population-based prediction algorithm which was validated using only Christchurch, New Zealand patients.

The adaptability of STAR includes BG level target range, measurement frequency, patient safety within a predefined desired risk, and local nutrition practices [13-14]. Given the notable differences in patient background and clinical environments, clinical staff are faced with a complex tradeoff in setting these limits: for example to either set a wider range of BG level target to optimize resources, at the expense of higher mortality rate [15], or set a narrow range which requires higher nurses intervention to 
ensure insulin treatment, at the expense of considerable patients discomfort, additional cost, or higher rate of hypoglycemia [16-17].

The objective of the study was to look into the feasibility of intergrating decision support on STAR protocol to decide on STAR options based on individual patient background upon ICU admission. As a result, the most appropriate patient treatment can be selected. Probabilistic Bayesian network [18] approach was used to interpret the possible relationship between the demographical, and admission data with STAR control performance variables for its capability to exploit correlation as well as causal relationship using intensive care patients data [19-21]. A proof of concept on static Bayesian inference was provided to prove the said feasibility.

\subsection{METHODOLOGY}

\subsection{Virtual Simulation Framework}

The method used to simulate the respond to demographical, and admission data towards any glycemic control is a physiological model-based virtual trial framework [22-23]. The framework is illustrated in Figure 1. Data such as nutrition and insulin are required, while record of patient specific conditions such as weight, height, and diabetic status can be recorded for expert intervention. The framework is divided into two stages, (i) Data fitting to generate per-patient insulin sensitivity (SI) profiles that acted as virtual patients, and (ii) simulation of outcomes using generated SI profiles. Glycemic level outcomes are a function of insulin sensitivity (SI), its variability, and the chosen control. In this study, the clinically validated ICING (Intensive Control InsulinNutrition-Glucose) physiological model [9] was used to fit any patient data and the chosen control was the STAR control. Part of the simulation results consisting of mean blood glucose (BG), total hours of treatment, and the number of BG measurements were incorporated in our decision support model's proof of concept.

\subsection{Bayesian Network}

Probabilistic Bayesian Network (BN) is a method that has various advantages over the stochastic method. It offers the flexibility to infer any variable in its model with certain confidence instead of fixing input and output variables, and has the ability to explain inferences using causal relationship in uncertain environments [24]. This was used to explore the feasibility to build the decision support. Building basic $\mathrm{BN}$ involves (i) learning process, and (ii) using it for inference test. Learning a BN consists of creating the qualitative part of the network which is the causal structure between variables, commonly known as Directed acyclic Graph (DAG), as well as the quantitative part of computing the set of conditional probability distribution (CPD) of variables. Resulting network is used as a classifier to perform probabilistic inference from multiple variables, such as calculating the value of $P$ (number of BG measurements | presence of diabetic).

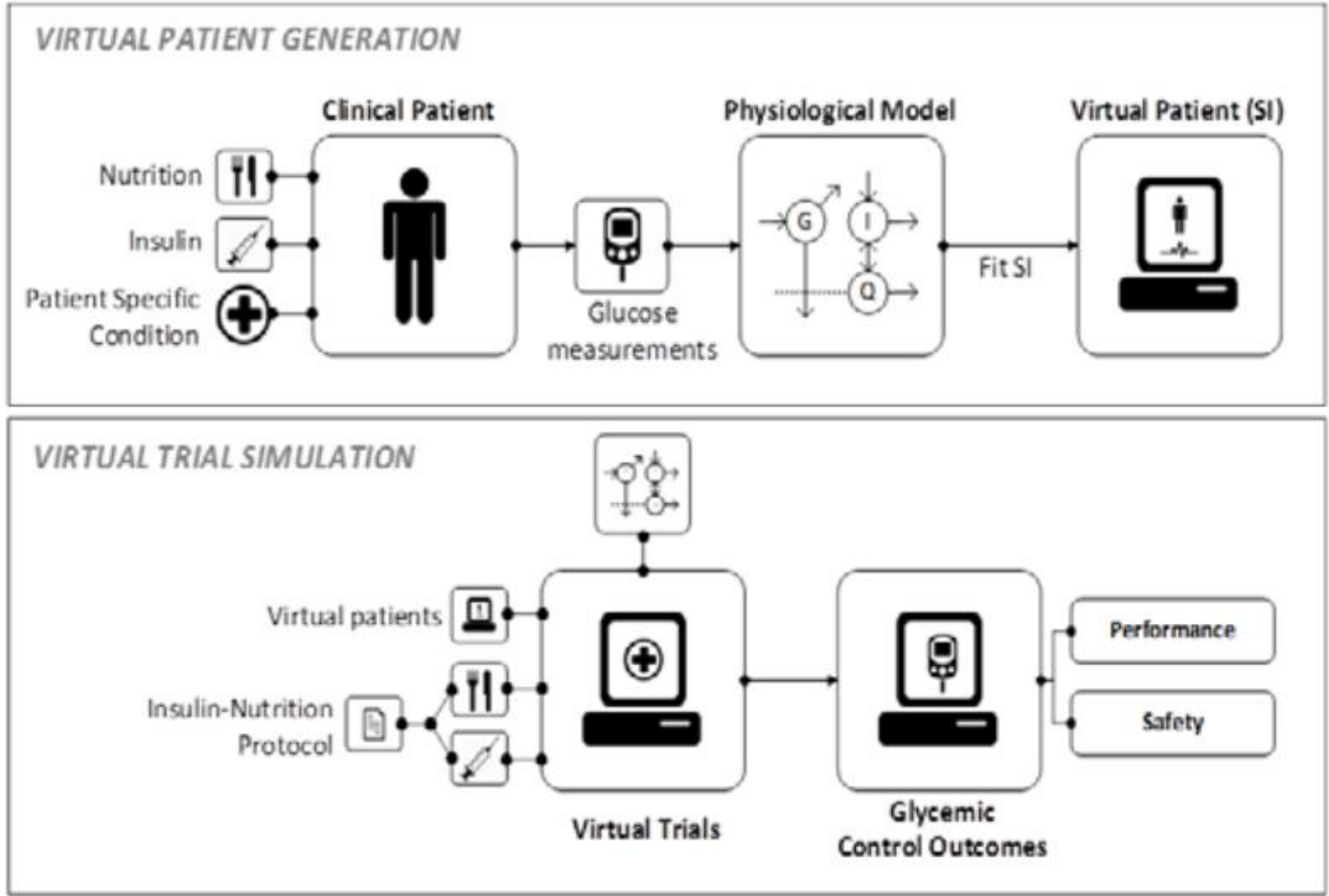

Figure 1 The STAR-ICING virtual trial framework used to simulate glycemic control outcomes [16] 
The primordial step to create BN was to identify the variables that define the description (causes), and optionally to set a target node. For each type of variable, a definition of values is equally important. In the ICU, most data comes in continuous form, but BN is most efficient when it is created using discrete values. Having the variables and their values, BN structure and CPD can be learned using different algorithms; from supervised, semi-supervised to unsupervised methods [25]. To choose the best structure and CPD, the 80:20 10 -fold cross validation test [26] using number of measurements as target node was proposed. This means that the validation algorithm iteratively selects 10 different learning and test sets, and based on those, learn the network, and test their performance. Performances were measured using the overall reliability, and precision metrics. Precision is the ratio of predictive positive cases to total number of actual cases, while reliability is the ratio of predicted positive cases to total number of predicted cases.

\subsection{Materials}

To provide the proof of concept, this case study involved 210 retrospective anonymous patient data from Hospital Tengku Ampuan Afzan (HTAA), Kuantan. Approval NMR-13-1592 was granted for this study by the medical research and ethics committee of the Hospital, and Ministry of Health, Malaysia. The data was selected randomly with skewed distribution on the patients' age and initial blood glucose level. Patients were originally treated with sliding scale glycemic control that dosed insulin based on patients' BG level, and previous insulin dose. The control was started when patients reached BG level superior to $10 \mathrm{mmol} / \mathrm{L}$, and continued to be greater than that within 1 hour. To maintain the BG level in targeted $B G$ level range, the patient was initially monitored hourly until BG level was within the goal for 2 hours, then every 4 hours. More details are provided in [27].

These patient data was then injected into the STARICING virtual trial framework to generate not only virtual patients, but also simulating their response to STAR control which flexibly offers 1-3 hourly treatment. For the purpose of this study, the default choice was the I longest intervention recommendation (between 3 hourly, 2 hourly and 1 hourly). BG level target range for STAR was set to $6.0-10.0 \mathrm{mmol} / \mathrm{L}$ following the same target range using sliding scale method. Safety hypoglycemia risk was set to be less than $5 \%$.

Once the outcomes were simulated, the 210 patient dataset comprising the per-patient demographic, and admission input variables were aligned with their STAR control simulated performance results. The complete dataset were then injected into BayesiaLab 7.0 software to discretize the continuous data, to learn the structure and CPD, and to test the target node inference reliability and precision. The results not only provided proof of concept on the feasibility to use this approach as STAR control decision support in the ICU, but also the perspective for needed improvement.

\subsection{RESULTS AND DISCUSSION}

The identification of variables and their values from the data is the trickiest task. They require expert opinions, are obtained through data analysis, or are the union of both. The process of identifying the best discrete values and the number of values from the variables is a precursor towards building the $\mathrm{BN}$. In this proof of concept, 10 demographic, and admission background variables were chosen to be added to the 3 control performance variables. Continuous data was discretized using the k-means method [28], limiting the discretization to 3 values. A decision was made after test results comparison between networks with 2 and 4 values. 8 out of the 13 proposed variables were discretized using this approach. The number of BG measurement was chosen as the target node to assess the feasibility of predicting the number of nurses' intervention, and the total length of stay, in an effort to reduce resources, and discomfort while assuring BG level performance is within target range. Table 1 shows the variables used in the provision of proof of concept as well as their values.

Table 1 Description of variables for proof of concept dataset

\begin{tabular}{llll}
\hline No. & Variables & Values \\
\hline 1 & $\begin{array}{l}\text { Number of BG } \\
\text { measurements }\end{array}$ & $<69 / 69-100 />100$ \\
\hline 2 & $\begin{array}{l}\text { Total hours on } \\
\text { treatment (hours) }\end{array}$ & $<110.2 / 110.2-150.4 />150.4$ \\
\hline 3 & $\begin{array}{l}\text { BG Mean (Geometric) } \\
\text { (mmol/L) }\end{array}$ & $>10 / 8-10 / 6-8$ \\
\hline 4 & $\begin{array}{l}\text { Initial BG values } \\
\text { (mmol/L) }\end{array}$ & $>18 / 14-18 / 10-18 /<10$ \\
\hline 5 & Diabetic & Yes (1)/No (0) \\
\hline 6 & Hypertension & Yes (1)/No (0) \\
\hline 7 & Other morbidity & Yes/None \\
\hline 8 & Category of admission & Surgical/Medical/Others \\
\hline 9 & Gender & Female/Male \\
\hline 10 & Age (Years) & $<43.1 / 43.1-61.9 />61.9$ \\
\hline 11 & Height (cm) & $<128.3 / 128.3-159.2 />159.2$ \\
\hline 12 & Weight (kg) & $<65 / 65-84.6 />84.6$ \\
\hline 13 & Ethnicity & $\begin{array}{l}\text { Malay/Indian/Chinese/Ot } \\
\text { hers }\end{array}$ \\
\hline
\end{tabular}

The resulting structure of the $\mathrm{BN}$ is presented in Figure 2. The green, red, blue and yellow coloured nodes represent the demographic background, admission condition, initial BG upon control start up, and the simulated outcomes from STAR control variables, respectively. "Number of measurements" as target node is highlighted in spiraled node. This structure was obtained using the Maximum Spanning Tree unsupervised learning strategy [295]. It advocates that "Diabetes Mellitus" status is central to the control results. The outgoing arcs point to the "Number of Measurements" as well as "Hypertension, "Initial BG", and "Height". While the direction of arcs potentially indicate causal relationship, such as the one to "Number of Measurements", others are examined as 
having a strong correlation to the diabetic status, thus to the target node. The structure of marginal probability distribution is presented in Figure 3. In this patient group, $63.67 \%$ of the patients were admitted due to medical complication, and among them, $64.49 \%$ were of Malay ethnicity. The percentage of diabetic vs. non diabetic and hypertension vs. non hypertension patients are about the same. It is also noted that, 87 of the patients have both diabetes and hypertension, and this explains the high correlation between the two nodes.

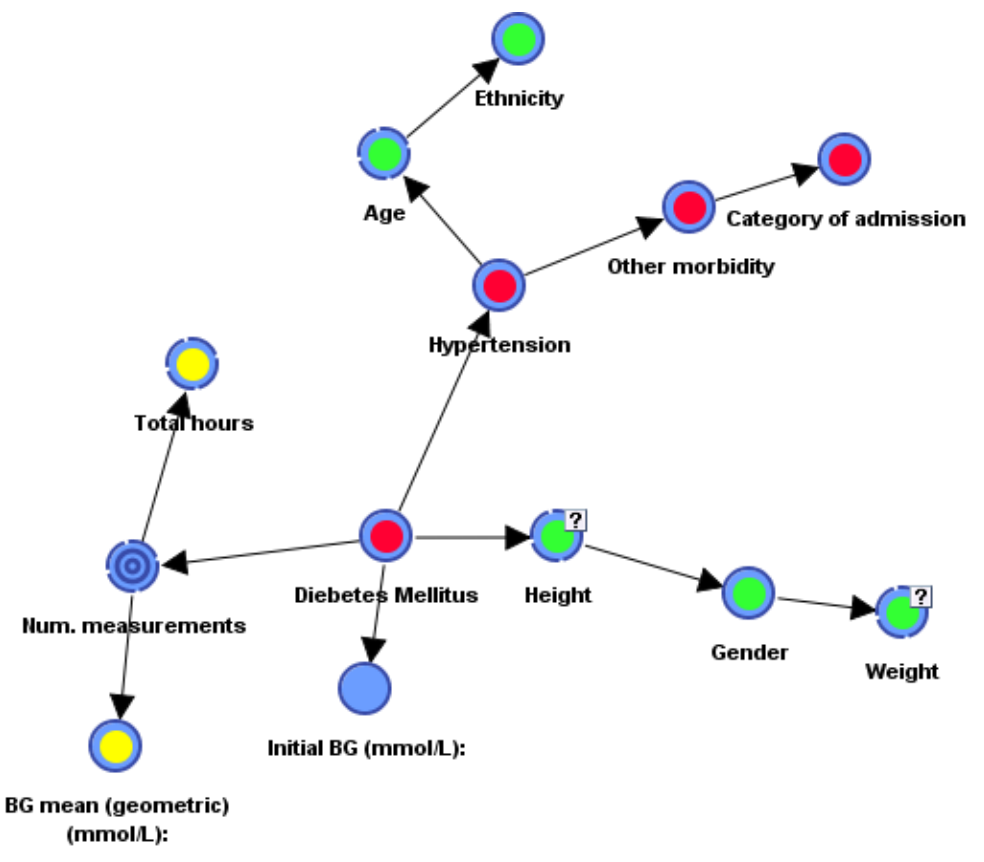

Figure 2 The Bayesian Network structure

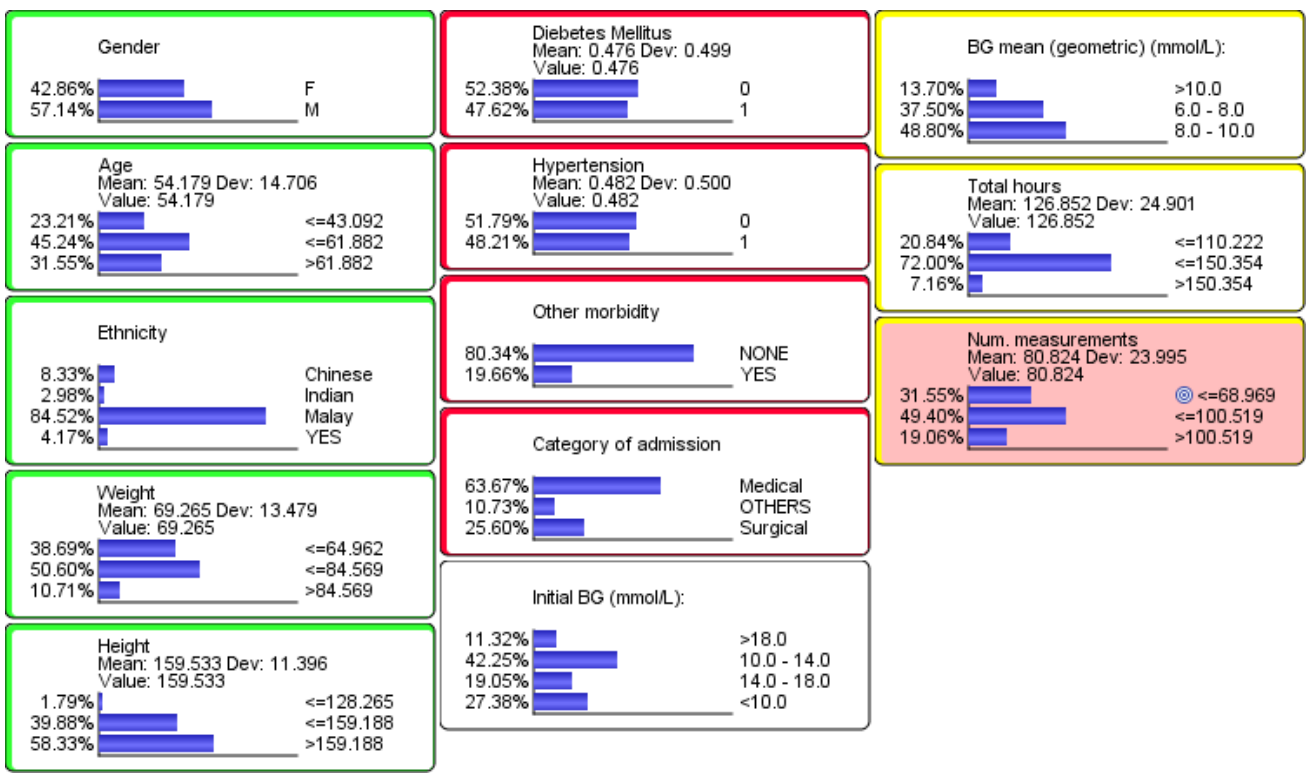

Figure $\mathbf{3}$ The probabilistic distribution of data of all variables and their states

Examples of $\mathrm{BN}$ inference results of individual patients are shown in Figures $4(a)$ and (b). Two representative patients were chosen based on their admission complications. Patient BSLOO1 is a 70 year old man with no diabetes, no hypertension, and no other morbidity who was admitted under the medical category. Whereas, Patient BSL025 is an 84 year old Chinese man with diabetes Mellitus, 
hypertension, and no other morbidity. To observe the results, hard evidence are posed per patient specific condition data (green bars), their targeted BG means, total hours, and number of measurements were correctly inferenced (highest probability, blue bars) by the $B N$.
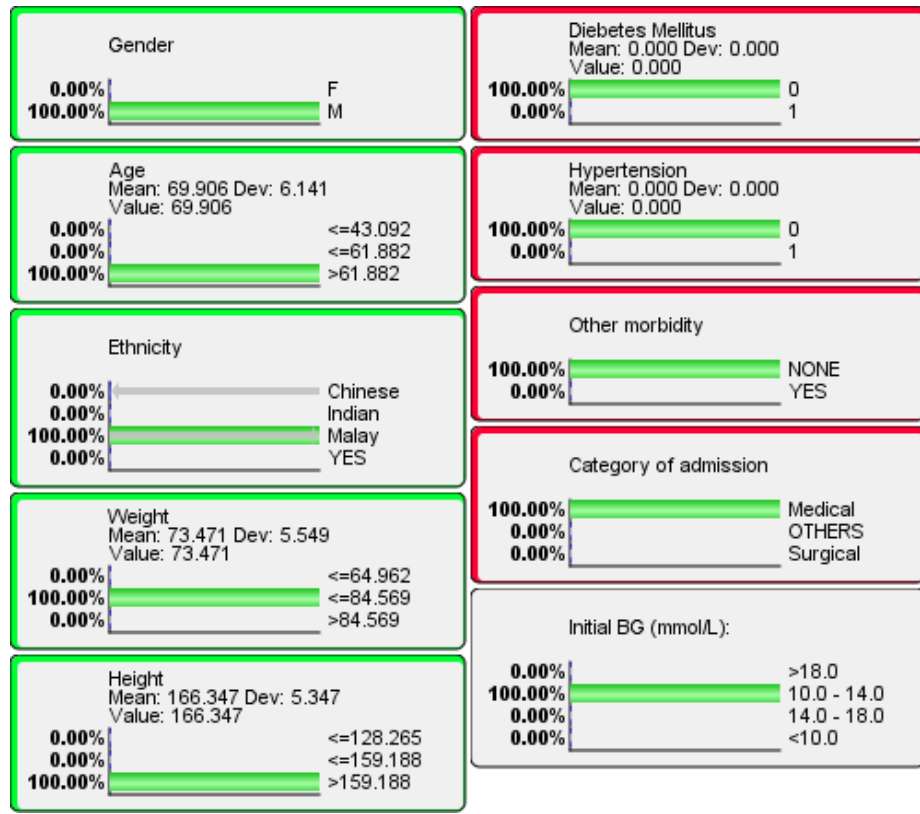

(a)
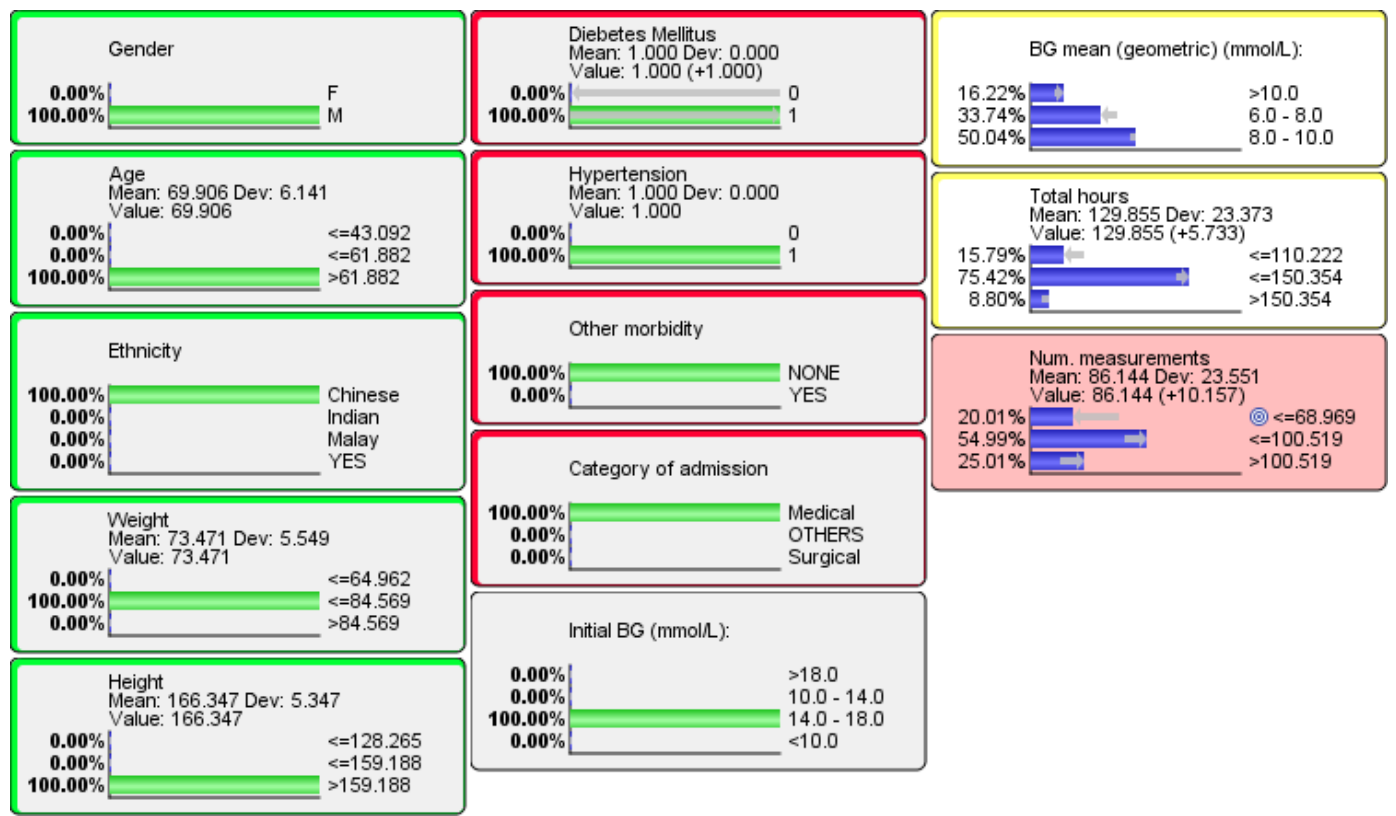

(b)

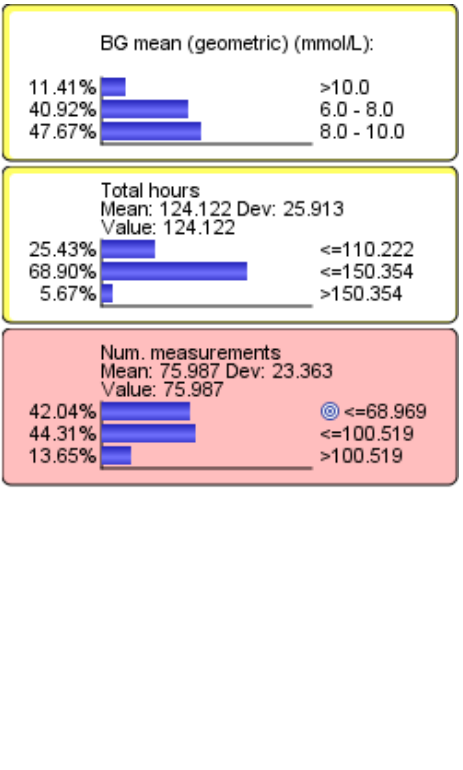




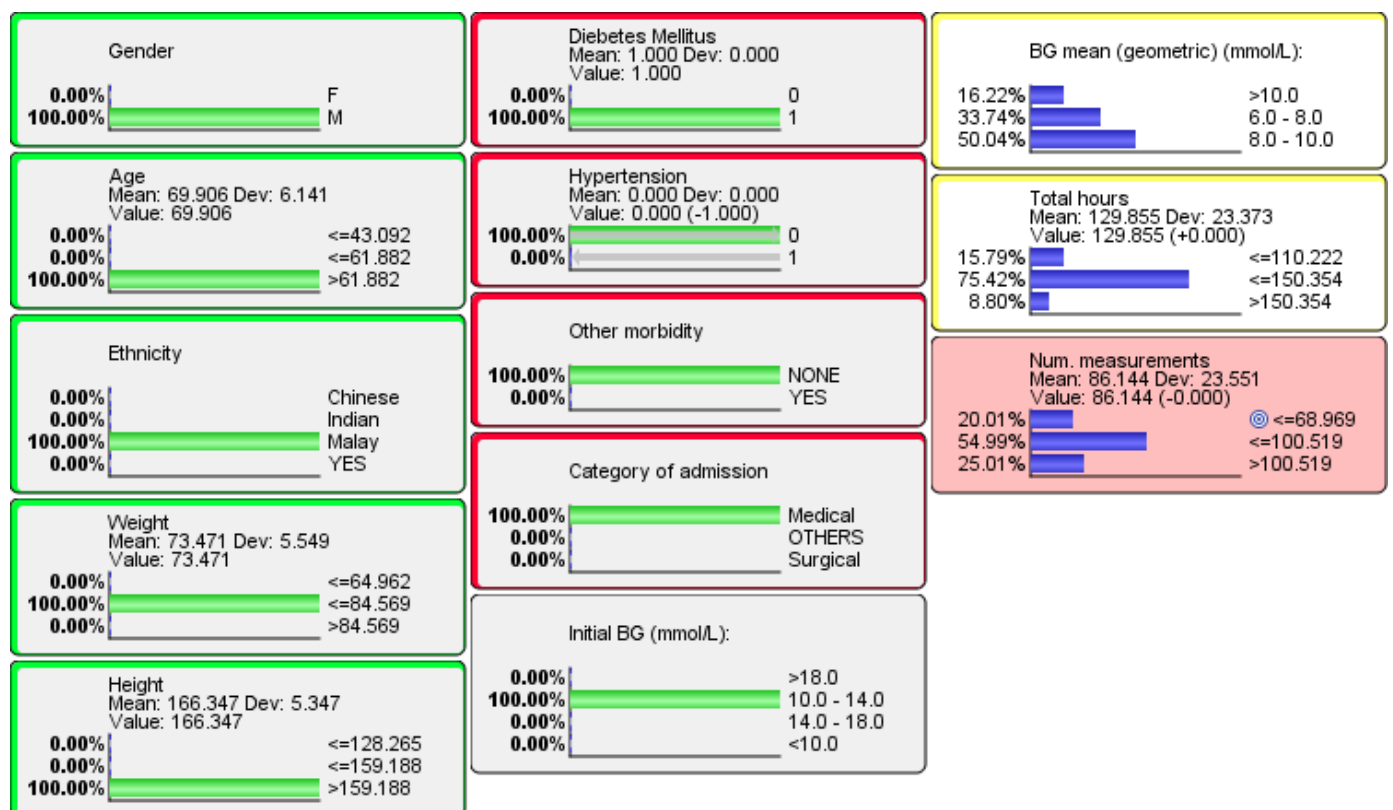

(a)
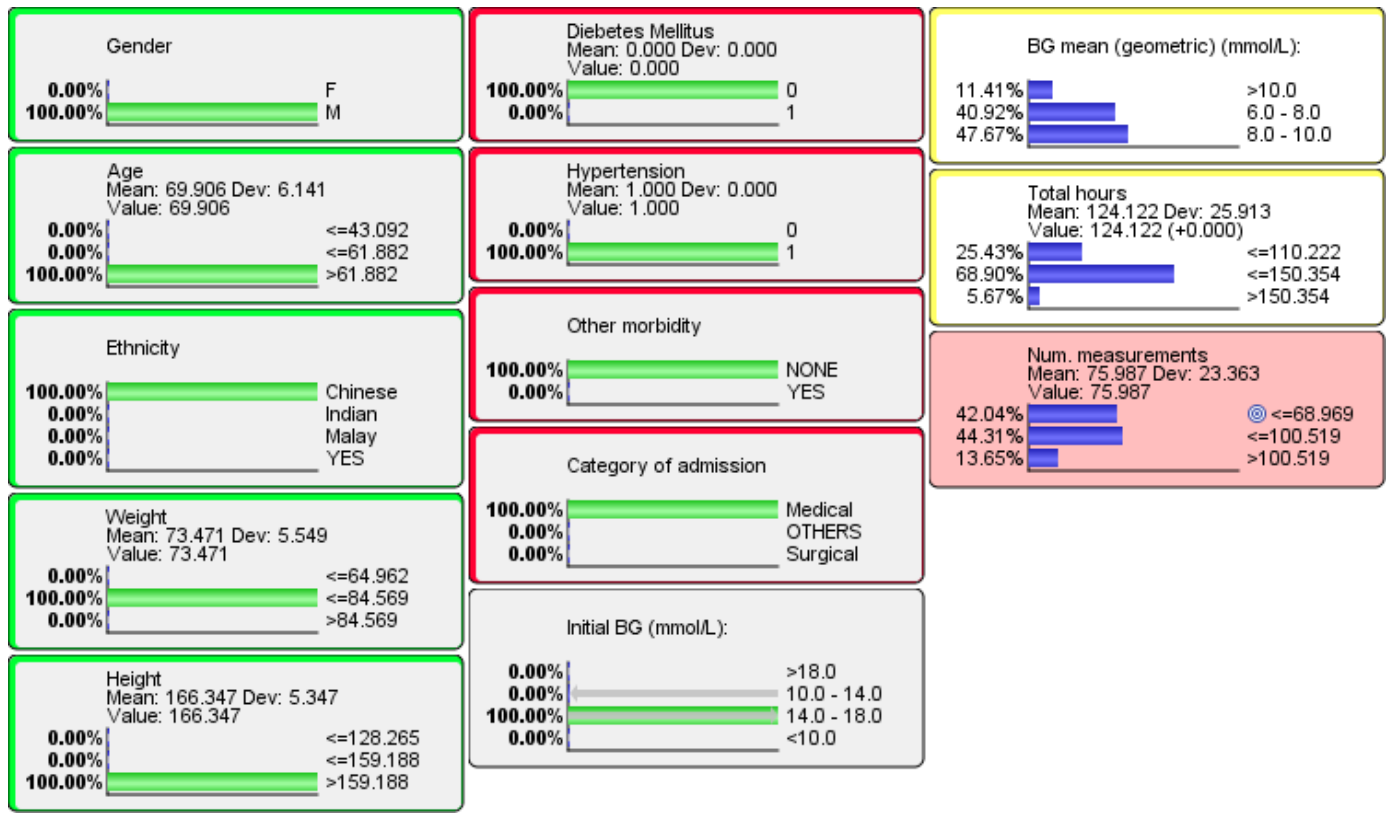

(b)

Figure 5 Examples from the same two patients when their diabetic status evidence are changed; (a) Patients BSLO01, and (b) BSLO25

The reliability and precision results on the test dataset (20\%, are 42 patients) are presented in Table 2. The numbers in the column represent the actual cases in the test dataset, while the numbers in the rows represent the number of $\mathrm{BN}$ predicted cases. The overall precision is $71.43 \%$, with false negative rate of $28.7 \%$, and overall reliability is $73.90 \%$. Although this result is not enough to confirm good performance of this specific network, we argue that it is due to the limited size of the data that was used to create, and test this BN (210 patients). Learning and testing with a bigger dataset will ensure a more precise $\mathrm{BN}$, thus becoming the immediate priority in validating this approach. 
Table 2 The target node inference confusion matrix of test dataset

\begin{tabular}{lccc}
\hline $\begin{array}{l}\text { Nb. Of } \\
\text { Occurrence }\end{array}$ & $<=68.969(12)$ & $<=100.519(19)$ & $>100.519(11)$ \\
\hline$<=68.969(9)$ & 9 & 0 & 0 \\
\hline$<=100.519(25)$ & 3 & 16 & 6 \\
\hline$>100.519(8)$ & 0 & 3 & 5 \\
\hline Reliability & $<=68.969(12)$ & $<=100.519(19)$ & $>100.519(11)$ \\
\hline$<=68.969(9)$ & $100.0 \%$ & $0 \%$ & $0 \%$ \\
\hline$<=100.519(25)$ & $12.0 \%$ & $64.0 \%$ & $24.0 \%$ \\
\hline$>100.519(8)$ & $0 \%$ & $37.5 \%$ & $62.5 \%$ \\
& & & \\
\hline Precision & $<=68.969(12)$ & $<=100.519(19)$ & $>100.519(11)$ \\
\hline$<=68.969(9)$ & $75.0 \%$ & $0 \%$ & $0 \%$ \\
\hline$<=100.519(25)$ & $25.0 \%$ & $84.2 \%$ & $54.5 \%$ \\
\hline$>100.519(8)$ & $0 \%$ & $15.8 \%$ & $45.5 \%$ \\
\hline
\end{tabular}

\subsection{CONCLUSION}

In the provision of proof of concept, we first acquired the performance of STAR control using virtual trial framework on 210 patient data, and then aligned the performance results with demographic, and admission information to build a Bayesian Network. This is the first step towards building a decision support system to be paired with the STAR control taking into account the personalized per-patient background. Based on the inference test, the $\mathrm{BN}$ that was developed is capable of classifying the control results correctly; "Number of Measurements", "Total Hours" and "BG Mean". It serves as the proof of concept to explore this method, and its integration in STAR control further. The real advantage lies in using these models as an inference tool for real time control prediction.

Secondly, BN is a method that is capable to be learned by integrating opinion of experts, but in this study it was done exclusively with data learning. To ensure a more reliable and a more generalized network for prediction, a proposed $\mathrm{BN}$ model be brainstormed with medical experts from the intensive care units, and if necessary, be validated with crossunit experts such as the concern of comorbidities.

\section{Acknowledgement}

Approval NMR-13-1592-18706 was granted to this study by HTAA and National Institute of Health $(\mathrm{NIH})$. The authors thankfully acknowledge HTAA ICU clinical team for their support and provision of data for this study. The authors also acknowledge FRGS Grant, Ministry of Higher Education, BOLD Scheme and UNITEN for their roles on the ongoing research.

\section{References}

[1] Krinsley, J. S., Chase, J. G., Gunst, J., Martensson, J., Schultz, M. J., Taccone, F. S., Wernerman, J., Bohe, J., De Block, C., Desaive, T., and Kalfon, P. 2017. Continuous Glucose Monitoring in the ICU: Clinical Considerations and Consensus. Critical Care. 21 (1): 197.

[2] Chase, J. G., Desaive, T., Bohe, J., Cnop, M., De Block, C., Gunst, J., Hovorka, R., Kalfon, P., Krinsley, J., Renard, E., and Preiser, J. C. 2018. Improving Glycemic Control in Critically III Patients: Personalized Care to Mimic the Endocrine Pancreas. Critical Care. 22(1): 182.

[3] Chase, J. G., Preiser, J. C., Dickson, J. L., Pironet, A., Chiew, Y. S., Pretty, C. G., Shaw, G. M., Benyo, B., Moeller, K., Safaei, S., and Tawhai, M. 2018. Next-generation, Personalised, Model-based Critical Care Medicine: A State-of-the Art Review of in Silico Virtual Patient Models, Methods, and Cohorts, and How to Validation Them. Biomedical Engineering Online. 17(1): 24.

[4] Saur, N. M., Kongable, G. L., Holewinski, S., O'Brien, K., and Nasraway, S. A. 2013. Software-guided Insulin Dosing: Tight Glycemic Control and Decreased Glycemic Derangements in Critically III Patients. Mayo Clinic Proceedings. Elsevier. 88(9): 920-929. DOI: https://doi.org/10.1016/j.mayocp.2013.07.003.

[5] Cochran, S., Miller, E., Dunn, K., Burgess, W. P., Miles, W., and Lobdell, K. 2006. Endotool TM Software for Tight Glucose Control for Critically III Patients: 260. Critical Care Medicine. 34(12): A68.

[6] Van Herpe, T., Mesotten, D., Wouters, P. J., Herbots, J., Voets, E., Buyens, J., De Moor, B., and Van den Berghe, G., 2013. LOGIC-insulin Algorithm-guided Versus Nursedirected Blood Glucose Control during Critical Illness: The LOGIC-1 Single-center, Randomized, Controlled Clinical Trial. Diabetes Care. 36(2): 188-194. DOI: https://doi.org/10.2337/dc12-0584.

[7] Evans, A., Shaw, G. M., Le Compte, A., Tan, C. S., Ward, L., Steel, J., Pretty, C. G., Pfeifer, L., Penning, S., Suhaimi, F., and Signal, M. 201 1. Pilot Proof of Concept Clinical Trials of Stochastic Targeted (STAR) Glycemic Control. Annals of Intensive Care. 1(1): 38. DOI: https://doi.org/10.1186/21105820-1-38.

[8] Lin, J., Lee, D., Chase, J. G., Shaw, G. M., Le Compte, A., Lotz, T., Wong, J., Lonergan, T., and Hann, C. E. 2008. Stochastic Modelling of Insulin Sensitivity and Adaptive Glycemic Control for Critical Care. Computer Methods and Programs in Biomedicine. 89(2): 141-152. DOI: http://dx.doi.org/10.1016/j.cmpb.2007.04.006.

[9] Lin, J., Razak, N. N., Pretty, C. G., Le Compte, A., Docherty, P., Parente, J. D., Shaw, G. M., Hann, C. E., and Chase, J. G. 2011. A Physiological Intensive Control Insulin-NutritionGlucose (ICING) Model Validated in Critically III Patients. Computer Methods and Programs in Biomedicine. 102(2): 192-205. DOI: https://doi.org/10.1016/j.cmpb.2010.12.008.

[10] Le Compte, A. J., Lee, D. S., Chase, J. G., Lin, J., Lynn, A., and Shaw, G. M. 2010. Blood Glucose Prediction Using Stochastic Modeling in Neonatal Intensive Care. IEEE Transactions on Biomedical Engineering. 57(3): 509-518. DOI: https://dx.doi.org/10.1 109/TBME.2009.2035517.

[11] Abu-Samah, A., Ahamad, N. H., Razak, N. N., Suhaimi, F. M., Jamaluddin, U. K., Ralib, A. M., Mat-Nor, M. B., Pretty, C. G., Dickson, J. L., and Chase, G. 2017. Model-based Insulin-Nutrition Administration for Glycemic Control in Malaysian Critical Care: First Pilot Trial. International Conference for Innovation in Biomedical Engineering and Life Sciences. Springer, Singapore. 189-196. DOI: https://doi.org/10.1007/978-981-10-7554-4_33.

[12] Stewart, K. W., Pretty, C. G., Tomlinson, H., Thomas, F. L., Homlok, J., Noémi, S. N., Illyés, A., Shaw, G. M., Benyó, B., and Chase, J. G. 2016. Safety, Efficacy and Clinical Generalization of the STAR Protocol: A Retrospective Analysis. Annals of Intensive Care. 6(1): 24. DOI: https://doi.org/10.1186/s13613-016-0125-9. 
[13] Evans, A., Le Compte, A., Tan, C. S., Ward, L., Steel, J., Pretty, C. G., Penning, S., Suhaimi, F., Shaw, G. M. Desaive, T., and Chase, J. G. 2012. Stochastic Targeted (STAR) Glycemic Control: Design, Safety, and Performance. Journal of Diabetes Science and Technology. 6(1): 102-115. DOI: http://dx.doi.org/ $10.1177 / 193229681200600113$.

[14] Fisk, L. M., Le Compte, A. J., Shaw, G. M., Penning, S., Desaive, T., and Chase, J. G. 2012. STAR Development and Protocol Comparison. IEEE Transactions on Biomedical Engineering. 59(12): 3357-3364. DOI: http://dx.doi.org/ 10.1109/TBME.2012.2214384.

[15] Van den Berghe, G., Wouters, P. J., Bouillon, R., Weekers, F., Verwaest, C., Schetz, M., Vlasselaers, D., Ferdinande, P. and Lauwers, P. 2003. Outcome Benefit of Intensive Insulin Therapy in the Critically III: Insulin Dose versus Glycemic Control. Critical Care Medicine. $31(2)$ : 359-366. DOI: 10.1097/01.CCM.0000045568.12881.10.

[16] Marik, P. E. and Preiser, J. C. 2010. Toward Understanding Tight Glycemic Control in the ICU: A Systematic Review and Meta-Analysis. Chest. 137(3): 544-551. DOI: https://doi.org/10.1378/chest.09-1737.

[17] Nice-Sugar Study Investigators. 2009. Intensive Versus Conventional Glucose Control in Critically III Patients. New England Journal of Medicine. 360(13): 1283-1297. DOI: https://doi.org/10.1056/NEJMoa0810625.

[18] Pearl, J. 2014. Probabilistic Reasoning in Intelligent Systems: Networks of Plausible Inference. Elsevier.

[19] Sierra, B., Serrano, N., LarrañAga, P., Plasencia, E. J., Inza, I., JiméNez, J. J., Revuelta, P., and Mora, M. L. 2001. Using Bayesian Networks in the Construction of a Bi-Level MultiClassifier. A Case Study Using Intensive Care Unit Patients Data. Artificial Intelligence in Medicine. 22(3): 233-248.

[20] Ramon, J., Fierens, D., Güiza, F., Meyfroidt, G., Blockeel, H., Bruynooghe, M., and Van Den Berghe, G. 2007. Mining Data from Intensive Care Patients. Advanced Engineering Informatics. 21 (3): 243-256.

[21] Wong, R. S. Y. and Ismail, N. A. 2016. An Application of Bayesian Approach in Modeling Risk of Death in an Intensive Care Unit. PloS ONE. 11 (3): e0151949.
[22] Chase, J. G., Suhaimi, F., Penning, S., Preiser, J. C., Le Compte, A. J., Lin, J., Pretty, C. G., Shaw, G. M. Moorhead, K. T., and Desaive, T. 2010. Validation of a Model-based Virtual Trials Method for Tight Glycemic Control in Intensive Care. Biomedical Engineering Online. 9(1): 84. DOI: https://doi.org/10.1186/1475-925X-9-84.

[23] Dickson, J. L., Stewart, K. W., Pretty, C. G., Flechet, M., Desaive, T., Penning, S., Lambermont, B. C., Benyo, B., Shaw, G. M., and Chase, G. 2017. Generalisability of a Virtual Trials Method for Glycaemic Control in Intensive Care. IEEE Transactions on Biomedical Engineering. DOI: http://dx.doi.org/10.1 109/TBME.2017.2686432.

[24] Kjaerulff, U. B. and Madsen, A. L. 2006. Probabilistic Networks for Practitioners-A Guide to Construction and Analysis of Bayesian Networks and Influence Diagrams. Department of Computer Science, Aalborg University, HUGIN Expert A/S.

[25] Margaritis, D. 2003. Learning Bayesian Network Model Structure from Data (No. CMU-CS-03-153). CARNEGIEMELLON UNIV PITTSBURGH PA SCHOOL OF COMPUTER SCIENCE.

[26] Kohavi, R. 1995. A Study of Cross-validation and Bootstrap for Accuracy Estimation and Model Selection. ljcai. 14(2): 1137-1145

[27] Luqman, H. M., Zulkifly, W. Z. W., Rosly, C. Z., Khalid, K., Jamaludin, U. K., Ralib, A. M., and Nor, M. B. M. 2016 , October. Performance of Blood Glucose Management Protocols in HTAA Intensive Care Unit. Automatic Control and Intelligent Systems (I2CACIS), IEEE International Conference on IEEE. 156-161. DOI: http://dx.doi.org/10.1 109//2CACIS.2016.7885307.

[28] Dougherty, J., Kohavi, R. and Sahami, M. 1995. Supervised and Unsupervised Discretization of Continuous Features. Machine Learning Proceedings. 194-202.

[29] Chow, C. and Liu, C. 1968. Approximating Discrete Probability Distributions with Dependence Trees. IEEE Transactions on Information Theory. 14(3): 462-467. DOI: https://dx.doi.org/10.1109/TIT.1968.1054142. 